\title{
COST REDUCTION IN TISSUE CULTURE I - SAVING OF WATER AND POWER
}

Faisal Mohamed Saadawy

Dept. of Ornamental Plant Researches and Landscape Design, Horticulture Research Institute, Agriculture Research Center, Giza, Egypt.

\begin{abstract}
Using tap water in preparing media instead of distilled water gave significant higher number of shoots and leaves, in addition to an insignificant increase in shoot fresh weight, shoot length and total chlorophyll content of both Gerbera and Lilium explants at multiplication stage.

At the rooting stage, in both plants the number of leaves and root length were higher in plantlets when using tap water than when using distilled water in media preparation. However, the effect was statistically significant on root length in case of Gerbera only, and on leaf number in case of Lilium only. Insignificant increments in plantlet fresh weight, shoot length, root fresh weight, root number and chlorophyll content of Gerbera and Lilium plantlets were found when using tap water than distilled water.

Using tap water instead of distilled water in the approximately 30 tissue culture labs in Egypt may save yearly an amount of 13635 $\mathrm{m}^{3}$ of tap water intended originally for human potable purposes, 1350000 kilowatt of electric power and L.E. 822476 as a total cost, taking into consideration that these figures may change from lab to lab, from time to time and from a country to the other. Details of these figures are mentioned in the economical study.
\end{abstract}

\section{Key Words: Tap water, Distilled water, Rare earth elements, Cost, Media preparation.}

\section{INTRODUCTION}

Chemically pure water does not exist for any appreciable length of time in nature. It is a must in almost all tissue culture labs to have one or more of the distillation units to provide them with the pure water needed to prepare the different types of media.

However, distilled water, because it is essentially mineral-free, is very aggressive, in that it tends to dissolve substances with which it is in contact. Notably, carbon dioxide from the air is rapidly absorbed, making the water acidic and even more aggressive.

The distillation process needs a lot of power (electrical energy), which is high in cost. Maintenance of distillation units can be a problem, depending on the design of the units. Minerals left behind in the boiling chamber can build up, interfering with the operation of the unit. Hard water can quickly clog a distiller. Because water is used also as a coolant liquid, waste of water during the distillation process will be very high.

This study aims to prove that using tap water instead of distilled water makes no difference either in the multiplication stage or the rooting one in two

Fayoum J. Agric. Res. \& Dev., Vol.19, No.1, January, 2005 
plants belonging to different classes, i.e. Dicotyledonae (Gerbera jamesonii) and Monocotyledonae (Lilium longiflorum). Proving this will help to:

1- Reduce the monthly costs of the tissue culture technique through cutting down electric power bills.

2- Save the big sum of money needed to buy water distillers especially for the commercial tissue culture labs. Price of these units ranges from about L.E. 2000 for the Chinese unit to 4000 for the Polish and 15000 for the German ones.

3- Stop wasting huge amounts of potable tap water that cost a lot to prepare and that will be more and more scarce in the future.

\section{MATERIALS AND METHODS}

This work was carried out in the Tissue Culture Laboratory, Zohriya Garden, Agricultural Research Center, Cairo, during the period from July to December 2004.

In vitro-produced explants of Lilium longiflorum (basal parts of the leaves) and Gerbera jamesonii cv. Festival (shoots) were used as a starting material.

Glass jars of $11.5 \mathrm{~cm}$ height and $6.5 \mathrm{~cm}$ diameter with their polypropylene caps were used. These jars were filled with $40 \mathrm{ml}$ of the Murashige and Skoog (1962) medium (MS) supplemented with either a cytokinin for explant multiplication or an auxin for rooting of the resultant shoots, and autoclaved at $121^{\circ} \mathrm{C}$ for 20 minutes under $1.05 \mathrm{~kg} / \mathrm{cm}^{2}$ pressure, left to cool and stored at $25 \pm 2^{\circ} \mathrm{c}$ for one week before being used.

Multiplication media were supplemented with benzyl adenine (BA) at $5 \mathrm{ppm}$ for Gerbera explants or $3 \mathrm{ppm}$ for Lilium. Rooting media were supplemented with 3-indoleacetic acid (IAA) at $2.5 \mathrm{ppm}$ for Gerbera, or indolebutyric acid (IBA) at $7 \mathrm{ppm}$ for Lilium.

For each plant, both types of media were prepared by using either distilled or tap water. These two treatments were arranged in a completely randomized design. Each treatment comprised 10 replicates (jars).

Explants were inoculated on the media (one explant/jar) under aseptic conditions using a laminar airflow cabinet. Jars were incubated for four weeks at $25 / 20^{\circ} \mathrm{C}$ (day/night) $\pm 2^{\circ} \mathrm{C}, 70 \%$ relative humidity. Two fluorescent tubes/shelf were installed at $30 \mathrm{~cm}$ above explants to provide light intensity of 2200-2400 lux at explant level for $16 \mathrm{~h}$. daily.

Data obtained in the multiplication stage were: shoot fresh weight $(\mathrm{g})$, shoot number, shoot length $(\mathrm{cm})$, leaf number and shoot content of total chlorophyll (mg/g fresh weight). Data obtained in the rooting stage were: shoot fresh weight, shoot length, leaf number, root number, root length, root weight and shoot content of total chlorophyll (according to Moran, 1982).

Data were statistically analyzed using SAS 1995 computer program, and means were compared by L. S. D. method according to Snedecor and Cochran (1980).

An economical study was conducted to assess costs of water distillation and amount of water wasted for cooling. A German distiller was used in this study.

Analysis of distilled and tap water was performed in the labs of the General Organization of Land Reclamation Project, Ministry of Agriculture, Dokki. Data of Nile water analysis were cited from Hamed (2003). (Table a)

Fayoum J. Agric. Res. \& Dev., Vol.19, No.1, January, 2005 
Table a. Analysis of distilled, tap and Nile water

\begin{tabular}{|c|c|c|c|c|}
\hline Parameter & Unit & Nile water * & Tap water $* *$ & Dist.water ** \\
\hline $\mathrm{pH}$ & & 7.2 & 7.1 & 6 \\
\hline E. C. & $\begin{array}{c}\mathrm{DS} / \mathrm{m} \\
\left(\mathrm{mmohs} / \mathrm{cm}^{3}\right)\end{array}$ & 0.32 & 0.27 & 0.0001 \\
\hline Total soluble salts & $\mathrm{mg} / \mathrm{l}$ & 204.8 & 172.8 & 0.064 \\
\hline \multicolumn{5}{|l|}{ Cations \& anions } \\
\hline $\mathrm{Ca}^{++}$ & $\mathrm{meq} / \mathrm{l}$ & 1.40 & 2.20 & \\
\hline $\mathrm{Mg}^{++}$ & $\mathrm{meg} / \mathrm{l}$ & 0.80 & 0.34 & \\
\hline $\mathrm{Na}^{+}$ & $\mathrm{meq} / \mathrm{l}$ & 0.70 & 0.12 & \\
\hline $\mathrm{K}^{+}$ & $\mathrm{meq} / \mathrm{l}$ & 0.10 & 0.04 & \\
\hline $\mathrm{CO}_{3}{ }^{=}$ & meq/l & 0.00 & 0.00 & \\
\hline $\mathrm{HCO}_{3}^{-}$ & $\mathrm{meq} / \mathrm{l}$ & 2.30 & 1.64 & \\
\hline $\mathrm{Cl}^{-}$ & $\mathrm{meq} / \mathrm{l}$ & 0.59 & 0.02 & \\
\hline $\mathrm{SO}_{4}{ }^{=}$ & $\mathrm{meq} / \mathrm{l}$ & 0.11 & 0.86 & \\
\hline \multicolumn{5}{|l|}{$\begin{array}{c}\text { Elements } \\
\text { concentration }\end{array}$} \\
\hline $\mathrm{Fe}$ & $\mathrm{mg} / \mathrm{l}$ & 0.0400 & & \\
\hline $\mathrm{Mn}$ & $\mathrm{mg} / \mathrm{l}$ & 0.0030 & & \\
\hline $\mathrm{Zn}$ & $\mathrm{mg} / \mathrm{l}$ & 0.0200 & & \\
\hline $\mathrm{Cu}$ & $\mathrm{mg} / \mathrm{l}$ & 0.0010 & & \\
\hline $\mathrm{Cd}$ & $\mathrm{mg} / \mathrm{l}$ & 0.0000 & & \\
\hline $\mathrm{Co}$ & $\mathrm{mg} / \mathrm{l}$ & 0.0000 & & \\
\hline $\mathrm{Ni}$ & $\mathrm{mg} / \mathrm{l}$ & 0.0002 & & \\
\hline $\mathrm{Pb}$ & $\mathrm{mg} / \mathrm{l}$ & 0.0010 & & \\
\hline $\mathrm{Cr}$ & $\mathrm{mg} / \mathrm{l}$ & 0.0000 & & \\
\hline
\end{tabular}

\section{RESULTS}

1 - Effect of water quality at multiplication stage (Tables 1-a and 1-b):

1-1- Effect of water quality on shoot fresh weight:

No significant effect for water quality was detected on shoot fresh weight of both Gerbera and Lilium explants. However, in both cases shoot fresh weight of explants grown on media prepared by tap water was higher than that of explants grown on media prepared by distilled water.

Table 1-a - Effect of water quality on multiplication of Gerbera

\begin{tabular}{cccccc}
\hline Water quality & $\begin{array}{c}\text { Shoot fresh } \\
\text { weight } \\
(\mathbf{g})\end{array}$ & $\begin{array}{c}\text { Shoot } \\
\text { No. }\end{array}$ & $\begin{array}{c}\text { Shoot length } \\
(\mathbf{c m})\end{array}$ & $\begin{array}{c}\text { Leaf } \\
\text { No. }\end{array}$ & $\begin{array}{c}\text { Total chlorophyll } \\
\text { (mg/g fresh } \\
\text { weight })\end{array}$ \\
\hline Dist. Wat. & 0.74 & 5.00 & 1.56 & 28.26 & 1.71 \\
Tap Wat. & 0.96 & 10.20 & 1.94 & 46.80 & 2.32 \\
\hline L.S.D. at 5\% & N.S. & 5.07 & N.S. & 8.25 & N.S. \\
\hline
\end{tabular}

Fayoum J. Agric. Res. \& Dev., Vol.19, No.1, January, 2005 
Faisal Mohamed Abdel Aleam Saadawy

Table 1-b - Effect of water quality on multiplication of Lilium

\begin{tabular}{cccccc}
\hline Water quality & $\begin{array}{c}\text { Shoot fresh } \\
\text { weight } \\
(\mathbf{g})\end{array}$ & $\begin{array}{c}\text { Shoot } \\
\text { No. }\end{array}$ & $\begin{array}{c}\text { Shoot length } \\
(\mathbf{c m})\end{array}$ & $\begin{array}{c}\text { Leaf } \\
\text { No. }\end{array}$ & $\begin{array}{c}\text { Total chlorophyll } \\
(\mathbf{m g} / \mathbf{g} \text { fresh } \\
\text { weight })\end{array}$ \\
\hline Dist. Wat. & 0.86 & 2.80 & 6.02 & 6.00 & 1.36 \\
Tap Wat. & 1.02 & 4.20 & 6.12 & 10.20 & 1.77 \\
\hline L.S.D. at 5\% & N.S. & 1.11 & N.S. & 2.39 & N.S. \\
\hline
\end{tabular}

1-2- Effect of water quality on shoot number:

Shoot number was significantly influenced by water quality. Using tap water in preparing media gave higher number of shoots than distilled water. This significant effect was found on both Gerbera and Lilium plants.

1-3- Effect of water quality on shoot length $(\mathrm{cm})$ :

Although using tap water resulted in shoots longer than those produced in the presence of distilled water in both Gerbera and Lilium, differences were statistically insignificant.

1-4- Effect of water quality on leaf number:

In both Gerbera and Lilium explants, leaf number was significantly higher in number when tap water was used in preparing the media, compared with using distilled water.

1-5- Effect of water quality on total chlorophyll content ( $\mathrm{mg} / \mathrm{g}$ fresh weight):

The effect of water quality had an insignificant effect on the total chlorophyll content of Gerbera and Lilium shoots. Although the difference was insignificant, this record was higher in both plants when tap water was used.

2 - Effect of water quality at rooting stage (Tables 2-a and 2-b):

2-1- Effect of water quality on plantlet fresh weight (g):

The effect of water quality on plantlet fresh weight of Gerbera and Lilium was found to be insignificant. Despite of this insignificance, this character was higher in case of tap water than that of distilled water.

Table 2-a - Effect of water quality on rooting of Gerbera

\begin{tabular}{lccccccc}
\hline $\begin{array}{c}\text { Water } \\
\text { quality }\end{array}$ & $\begin{array}{c}\text { Plantlet } \\
\text { fresh } \\
\text { weight }(\mathbf{g})\end{array}$ & $\begin{array}{c}\text { Shoot } \\
\text { length } \\
(\mathbf{c m})\end{array}$ & $\begin{array}{c}\text { Leaf } \\
\text { No. }\end{array}$ & $\begin{array}{c}\text { Root fresh } \\
\text { weight } \\
(\mathbf{g})\end{array}$ & $\begin{array}{c}\text { Root } \\
\text { No. }\end{array}$ & $\begin{array}{c}\text { Root } \\
\text { length } \\
\text { (cm) }\end{array}$ & $\begin{array}{c}\text { Total chlorophyll } \\
\text { (mg/g fresh } \\
\text { weight) }\end{array}$ \\
\hline Dist. Wat. & 0.32 & 3.34 & 5.80 & 0.08 & 4.20 & 7.24 & 1.36 \\
Tap Wat. & 0.34 & 3.60 & 6.40 & 0.10 & 4.80 & 8.42 & 1.43 \\
\hline L.S.D. at 5\% & N.S. & N.S. & N.S. & N.S. & N.S. & 1.06 & N.S. \\
\hline
\end{tabular}

Table 2-b - Effect of water quality on rooting of Lilium

\begin{tabular}{lccccccc}
\hline Water quality & $\begin{array}{c}\text { Plantlet } \\
\text { fresh } \\
\text { weight }(\mathbf{g})\end{array}$ & $\begin{array}{c}\text { Shoot } \\
\text { length } \\
\text { (cm) }\end{array}$ & $\begin{array}{c}\text { Leaf } \\
\text { No. }\end{array}$ & $\begin{array}{c}\text { Root fresh Root } \\
\text { weight } \\
\text { (g) }\end{array}$ & $\begin{array}{c}\text { Root } \\
\text { No. }\end{array}$ & $\begin{array}{c}\text { Total chlorophyll } \\
\text { (cm) }\end{array}$ & $\begin{array}{c}\text { (mg/g fresh } \\
\text { weight) }\end{array}$ \\
\hline Dist. Wat. & 4.93 & 16.00 & 19.20 & 1.18 & 8.29 & 2.96 & 1.35 \\
Tap Wat. & 5.75 & 18.00 & 28.00 & 1.71 & 6.04 & 3.24 & 1.61 \\
\hline L.S.D. at 5\% & N.S. & N.S. & 5.15 & N.S. & N.S. & N.S. & N.S. \\
\hline
\end{tabular}

Fayoum J. Agric. Res. \& Dev., Vol.19, No.1, January, 2005 
2-2- Effect of water quality on shoot length $(\mathrm{cm})$ :

Water quality did not affect shoot length significantly. However, shoots grown on tap water media were longer than those on distilled water media.

2-3- Effect of water quality on leaf number:

In both Gerbera and Lilium the number of leaves was higher in plantlets provided with tap water than when using distilled water. However, this effect was statistically significant in case of Lilium only.

2-4- Effect of water quality on root fresh weight (g):

Water quality failed to affect root fresh weight significantly. However, an insignificant increase in this character was observed in case of both Gerbera and Lilium when tap water was used in media preparation.

2-5- Effect of water quality on root number:

In both Gerbera and Lilium, water quality did not affect root number significantly. Apart from this result, roots produced in the presence of tap water were greater in number than those of plantlets grown on distilled water media. However, this situation was reversed in case of Lilium, where number of roots was higher when using distilled water than when using tap water in media preparation.

2-6- Effect of water quality on root length $(\mathrm{cm})$ :

Roots of Gerbera plantlets were significantly longer as a result of depending upon tap water compared with distilled water. The same trend was detected also in case of Lilium, although the effect was statistically insignificant.

2-7- Effect of water quality on shoot total chlorophyll content $(\mathrm{mg} / \mathrm{g}$ fresh weight):

Chlorophyll content of either Gerbera or Lilium shoots was higher in plantlets grown on media prepared with tap water than the same content in plantlets grown on media prepared with distilled water, although this influence was insignificant.

\section{DISCUSSION}

Among the many problems facing the tissue culture technique, if not the most important one, is the big sum of money needed to purchase the expensive equipments such as water distillers. The huge amount of water necessary for cooling distillation units represents a great loss of a very important resource that becomes more and more scarce in these days, i.e. potable water.

Using tap water instead of distilled one in order to cut down the already high expenses of tissue culture technique and to preserve the important factor of human life was tried by some researches. Ganapathi et al (1995) described a simple, low-cost method for the micropropagation of banana cv. Basrai. They remarked that tap water can be substituted for distilled water. The cheapest method for rooting and development of plantlets from shoot tips was on a medium containing tap water. Sharma and Singh (1995) investigated the effects of replacing distilled water with tap water in preparing the medium for culturing explants from in vitro-cultured shoots of ginger (Zingiber officinale) cv. Himachal Local. They found that the use of tap water gave good results. This technique can be used to reduce the cost of micropropagation. Belarmino and Gabon (1999) mentioned that to reduce the cost of producing in vitro plants of Chrysanthemum morifolium, non-distilled water can be used as a

Fayoum J. Agric. Res. \& Dev., Vol.19, No.1, January, 2005 
cheap substitute without affecting the quality of micropropagated plants. Tissue cultured chrysanthemum plants were normal, vigourous and flowered profusely in the field.

In addition, tap water proved to be more beneficial in some documented works. Punia et al (2000) studied the effects of using water from different sources on sugarcane (cultivars $\mathrm{CoH} 92$ and $\mathrm{CoH} 99$ ) shoot multiplication. They ascertained that ordinary tap water was better for the preparation of propagation media than distilled water from water purifiers.

Water content of rare earth elements (in very small amounts) may explain the effect of tap water in promoting some explant characters in vitro and crop yield in vivo. Shelton (2004) stated that while falling as rain, water picks up small amounts of gases, ions, dust, and particulate matter from the atmosphere. Then, as it flows over or through the surface layers of the earth, it dissolves and carries with it some of almost everything it touches, including that which is dumped into it by man.

HongMei and XiaoPing (2001) found that $\mathrm{La}\left(\mathrm{NO}_{3}\right)_{3}$ at different concentrations (1-100 mg/litre) affected explant percentage of differentiation as well as the number of roots and dry matter contents of stems, leaves and roots. Media with $1-50 \mathrm{mg} \mathrm{La}\left(\mathrm{NO}_{3}\right)_{3} /$ litre increased the number and length of roots, and the percentages of dry matter of stems, leaves and roots, but that with $100 \mathrm{mg} \mathrm{La}\left(\mathrm{NO}_{3}\right)_{3} /$ litre recorded an inverse effect. Maheswaran et al (2001) remarked that the use of rare earth elements (REE) in agriculture has been practiced in China since 1972. Increases in crop yield range between 8 and $50 \%$ and common responses in temperate crops of 8 to $10 \%$ were found. These responses are reported to be most probable when soils contain low available REE $(<10 \mathrm{mg} / \mathrm{kg}$, i.e. 5 and $10 \mathrm{~kg} / \mathrm{ha})$. FaDi and Bin (2002) observed that $\mathrm{La}^{3+}$ could stimulate the callus formation, growth and bud differentiation of Gerbera jasmesonii cv. Sunbird at low concentration. The suitable concentration was $10 \mathrm{mg} /$ litre in receptacle explants. Over this concentration, the bud initiation was inhibited and several explants turned brown. In leaf explants, the suitable concentration for callus formation and growth was $15 \mathrm{mg} / \mathrm{litre}$, and $30 \mathrm{mg} /$ litre for bud initiation and multiplication. WeiPing et al (2002) mentioned that the optimum concentration of $\mathrm{La}\left(\mathrm{NO}_{3}\right)_{3}$ at $1-3 \mu \mathrm{mol} /$ litre $(0.33-1.00 \mathrm{ppm})$ in the rooting medium of loquat (Eriobotrya japonica) plantlets could increase the rate and the fresh weight of rooting, promote the length of root, and increase the activities of peroxidase and nitrate reductase.

Physiological and biochemical explanation for these effects might be found in the references. Hong and Chen (1996) cultured Cymbidium sinense rhizomes on 1/2-strength MS medium supplemented with benzyladenine (BA) at $1 \mathrm{ppm}$, naphthalene acetic acid (NAA) at $1 \mathrm{ppm}$ and lanthanum (La) at 10 $\mathrm{mg} / \mathrm{litre}$ ). They stated that chloroplast development was enhanced by La; there were many more lamellae and osmiophilic granules in the stroma, and development was faster than in the control. Similarly mitochondrial development was enhanced by La, and mitochondrial volume was greater than in the controls. The chromatin content of the nucleus was increased by $\mathrm{La}$ treatment. Lopez-Serrano and Ros-Barcelo (1996) working on grape cv. Monastrell cell suspension cultures reported that the effectiveness of cations in lowering peroxidase activity followed the order: $\mathrm{La}>\mathrm{Cd}=\mathrm{Hg}>\mathrm{Ni}=\mathrm{Zn}=\mathrm{Co}$ $>\mathrm{Li}$, which is in accordance with their valence and with ionic radius. $\mathrm{La}^{3+}$ is

Fayoum J. Agric. Res. \& Dev., Vol.19, No.1, January, 2005 
the only cation together with $\mathrm{Al}^{3+}$ that belongs to class $\mathrm{A}$ metals, with a preference sequence for cellular ligands. XueFen et al (2003) conducted an experiment with 10th generation banana plantlets in MS medium with $4 \mathrm{mg}$ $\mathrm{BA}$ and $0.2 \mathrm{mg}$ NAA/litre. They added different concentrations of rare earth elements collected from a mine in Inner Mongolia. These consisted of 13.5\% cerium nitrate, $7.33 \%$ lanthanum nitrate and $4.07 \%$ neodymium nitrate. They reported that treatment with $10-15 \mathrm{mg} /$ litre of these rare elements promoted bud differentiation, and increased the leaf chlorophyll content, respiration rate and peroxidase activity. However, when the concentration of rare earth elements was increased to $30 \mathrm{mg} /$ litre, inhibitory effects appeared.

Sometimes there was no difference between the two types of water. This also means a privilege in favor of tap water. Sunandakumari et al (2004) stated that an efficient protocol for the rapid multiplication of the herbal spice Mentha piperita through axillary bud multiplication and ex vitro rooting was established using MS medium. Media prepared with tap water and those prepared with double distilled water did not show significant difference in the in vitro induction of shoots/node and roots/shoot. Using tap water made the protocol economic.

Economical study

An economical study was carried out through a survey of three tissue culture labs, namely:

1 - Tissue Culture Lab, Zohriya Garden.

2- Tissue Culture Lab, Horticulture Department, Faculty of Agriculture, Ain Shams University.

3- Tissue Culture Lab, Virus Department, Plant Pathology Institute, Agric. Research Center.

Prices of electric power and water consumption were calculated according to official bills on the commercial scale.

A German-made distilling unit that costed L.E. 15000 produced 7.51 . of distilled water/h. This unit took $10 \mathrm{~min}$ to warm up, during which it wasted 15 1. of water. Given that a commercial tissue culture lab consumes 1001 . of media/day, it took the unit $16.5 \mathrm{~h}$. to produce $100 \mathrm{l}$. of distilled water every day. During this time this unit needed $1500 \mathrm{l}$. of water, wasted for cooling. As the unit consumes 9 kilowatt/h. of electric power, a total of 148.5 kilowatt will be needed to produce 1001 . of distilled water.

This could be summarized in the following points (Table 3):

To get 100 l. of distilled water every day

Time needed $=16.5 \mathrm{~h}$.

Water wasted during warming up $=151$.

Water wasted for cooling $=15001$.

Total wasted water $=15151$.

Electric power for warming up $=1.5$ kilowatt

Electric power for distilling $=148.5$ kilowatt

Total electric power $=150$ kilowatt

Given that there are about 300 working day/year, and there are about 30 tissue culture labs in Egypt, This means 9000 working day/year in Egypt

Total wasted water/year for 30 labs $=13635 \mathrm{~m}^{3}$ as $1 \mathrm{~m}^{3}$ of water costs L.E. $0.36+$ L.E. 0.225 duties $=$ L.E. 0.585

Fayoum J. Agric. Res. \& Dev., Vol.19, No.1, January, 2005 
Faisal Mohamed Abdel Aleam Saadawy

Cost of total wasted water/year for 30 labs $=$ L.E. 7976

as 1 kilo watt/hour costs L.E. 0.27

Total electric power/year for 30 labs $=1350000$ kilowatt

Cost of total electric power/year for 30 labs = L.E. 364500

Price of distilling unit $=$ L.E. 15000

Supposing this unit will last for 10 years,

Cost of distilling unit/year $=$ L.E. 1500

For 30 tissue culture labs,

Total cost of distilling units/year = L.E. 450000

Table (3). Summary of the economical study

\begin{tabular}{|c|c|}
\hline Item & \\
\hline Total wasted water/year for 30 labs & $13635 \mathrm{~m}^{5}$ \\
\hline Cost of total wasted water/year & 7976 \\
\hline Cost of total electric power/year & L.E. 364500 \\
\hline Total cost of distilling units/year & L.E. 450000 \\
\hline Grand total costs & L.E. 822476 \\
\hline
\end{tabular}

Therefore, it is recommended to depend upon tap water for media preparation in tissue culture labs in order to save a big deal of money and to preserve the very precious potable water.

\section{REFERENCES}

Belarmino, M.M. and C.F. Gabon (1999). Low-cost micropropagation of chrysanthemum (Chrysanthemum morifolium L.) through tissue culture. Philippine J. Sci., 128(2): 125-143.

FaDi, C. and C. Bin (2002). Effects of $\mathrm{La}^{3+}$ on tissue culture of Gerbera jasmesonii 'Sunbird'. Acta Hort. Sinica, 29(4): 383-385.

Ganapathi, T.R.; J.S.S. Mohan; P. Suprasanna; V.A. Bapat and P.S. Rao (1995). A low-cost strategy for in vitro propagation of banana. Current Science, 68(6): 646-650.

Hamed, M.A. (2003). Effect of using sewage effluents on soil and some oil crops characteristics. Ph.D. Thesis. Soil Dept., Fac. Agric., Moshtohr, Zagazig Univ., Egypt.

Hong, $L$ and R. Chen (1996). The effect of lanthanum on the development of several organelles in the rhizome of Cymbidium sinense. Journal of Tropical and Subtropical Botany, 4(3):56-59.

HongMei, D. and Z. XiaoPing (2001). Effects of rare earth on the propagation and growth of spring chrysanthemum in vitro. J. Shanghai Agric. College, 19(2):102-104.

Lopez-Serrano, M. and A. Ros Barcelo (1996). Effect of metal ions on peroxidase activity from grapevine cells. Plant Physiology and Biochemistry (Paris), 34(6):827-832.

Maheswaran, J; B. Meehan; N. Reddy; K. Peverill and S. Buckingham (2001). Impact of Rare Earth Elements on plant physiology and productivity. Rural Industries Research \& Development Corporation, Australian

Fayoum J. Agric. Res. \& Dev., Vol.19, No.1, January, 2005 
Government, RIRDC Publication No 01/145 RIRDC Project No DAV-122A.

Moran, R. (1982). Formulae for determination of chlorophyllous pigments extracted with N-N dimethyl-formamide. Plant Physiol., 69:1376-1381.

Murashige, T. and F. Skoog (1962). A revised medium for rapid growth and bio-assay with tobacco tissue culture. Physiolgia Plantarum 15:473-497.

Punia, A.; R.K. Jain and A.R. Sehrawat (2000). Efficient and costeffective micropropagation of two early maturing varieties of sugarcane (Saccharum spp.). Indian Sugar,50(9): 611618.

Sharma, T.R. and B.M. Singh (1995). Simple and cost-effective medium for propagation of ginger (Zingiber officinale). Ind. J. Agric. Sci., 65(7): 506-508.

Shelton, T. B. (2004). Interpreting Drinking Water Quality Analysis: What do the numbers mean? Water Resources Management. Cook College-Rutgers University New Brunswick NJ 08903.

Snedecor, G. W. and W. G. Cochran (1980). Statistical Methods, $6^{\text {th }}$ ed., Iowa State Univ. Press, Iowa, USA.

Sunandakumari, C.; K.P. Martin; M. Chithra; S. Sini and P.V. Madhusoodanan (2004). Rapid axillary bud proliferation and ex vitro rooting of herbal spice, Mentha piperita $\mathrm{L}$. Ind. J. Biotech., 3(1):108-112.

WeiPing, S.; H. FaShui and W. ZhiGang (2002). Effects of Lanthanum element on the rooting of loquat plantlet in vitro. Biological Trace Element Research, 89(3):277-284.

XueFen, L.; H. JianPo; Z. XiJong; T. WanWen; H. YingPing and W. YuHui (2003). Effect of rare earth elements on the growth of in vitro plantlets of banana. South China Fruits, 32 (2): $30-31$. 


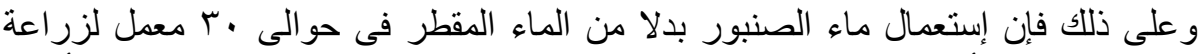

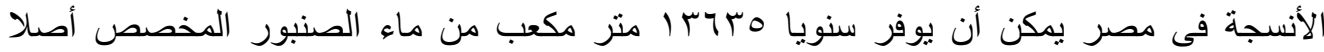

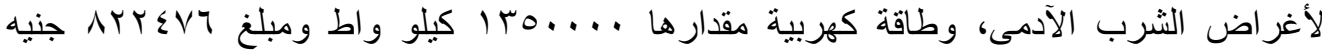

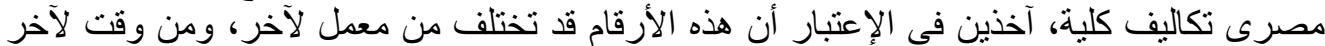

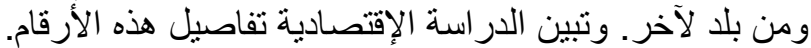

Fayoum J. Agric. Res. \& Dev., Vol.19, No.1, January, 2005 